\title{
ECOLOGICAL STUDY OF PARIS POLYPHYLLA SM.
}

\author{
Madhu K.C. ${ }^{1 *}$, Sussana Phoboo ${ }^{2}$ and Pramod Kumar Jha ${ }^{2}$ \\ ${ }^{1}$ Nepal Academy of Science and Technology, Khumaltar, Kathmandu \\ ${ }^{2}$ Central Department of Botany, Tribhuvan Univeristy, Kirtipur, Kathmandu \\ *Email: madhoo08@gmail.com
}

\begin{abstract}
Paris polyphylla Sm. (Satuwa) one of the medicinal plants listed as vulnerable under IUCN threat category was studied in midhills of Nepal with the objective to document its ecological information. The present study was undertaken to document the ecological status, distribution pattern and reproductive biology. The study was done in Ghandruk Village Development Committee. Five transects were laid out at 20-50m distance and six quadrats of $1 \mathrm{~m}$ x $1 \mathrm{~m}$ was laid out at an interval of $5 \mathrm{~m}$. Plant's density, coverage, associated species, litter coverage and thickness were noted. Soil test, seed's measurement, output, viability and germination, dry biomass of rhizome were also studied. The average population density of the plant in study area was found to be low $\left(1.78 \mathrm{ind} . / \mathrm{m}^{2}\right)$. The plant was found growing in moist soil with high nutrient content. No commercial collection is done in the study area but the collection for domestic use was found to be done in an unsustainable manner. Seed viability was found low and the seeds did not germinate in laboratory conditions even under different chemical treatments. The plant was found to reproduce mainly by vegetative propagation in the field. There seems to be a need for raising awareness among the local people about the sustainable use of the rhizome and its cultivation practice for the conservation of this plant.
\end{abstract}

Key words: Ghandruk, viability, germination, rhizome, sustainable.

\section{INTRODUCTION}

Knowledge about distribution and ecological features of the plants helps to decrease over exploitation by encouraging sustainable and discrete collection of medicinal plant from the world (Bhattacharya and Sharma 2008). A total of 138 native vascular plants taxa are threatened in Nepal, including over 50 species of medicinal plants (CAMP 2001, Tandon et al. 2001). Among them Paris polyphylla $\mathrm{Sm}$. is listed under vulnerable category (V) by IUCN and CAMP. No quantitative information on availability/population of Paris polyphylla is available in Nepal and there has been no research regarding the ecology of this species. The current research regarding this species at present is confined only to biochemical work. Understanding the ecology of individual species is important for conservation and for cultivation purposes. The present study focuses on the detailed 
study of the plant, Paris polyphylla regarding its ecological status, biomass production, seed output and regeneration. The specific objective of the present research was to find the status of Paris polyphylla in Ghandruk VDC of Annapurna Conservation Area and to find out the factors influencing growth, distribution, population, biomass production of rhizome and regeneration potentiality of Paris polyphylla.

Paris polyphylla Smith, Synonym - Daiswa polyphylla (Sm.) Raf., Family: Liliaceae., Local name Satuwa, is an important perennial medicinal plant growing under the canopy of moist temperate forest in Nepal.

Rhizome of Paris polyphylla is widely used in Nepal as an antihelmintic, antispasmodic, digestive stomachic, expectorant and vermifuge (IUCN 2004, Bhattarai and Ghimire 2006). Powder from rhizome is used for fever and food poisoning. Root paste is applied as an antidote to snake bites and poisonous insect bites and also to alleviate narcotic effects. Chewing a piece of the root is believed to heal internal wounds below the throat while applied on cut it heals external wounds. It produces vasoconstriction in kidney, vasodilation in spleen and limbs and stimulates the isolated intestine (Dutta 2007, Baral and Kurmi 2006). Pieces of the root are fed to cattle with diarrhoea and dysentery.

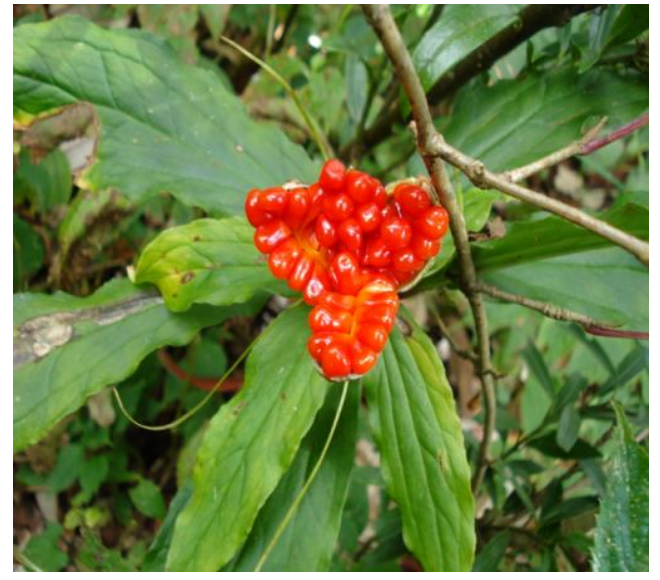

Study species (Paris polyphylla)
It is an important folk medicinal herb of China. Its rhizomes are used for injuries from falls, fractures, convulsions and strains (Liang 2000). Whole plant can be used as febrifuge, while roots can be used as analgesic, antiphlogistic (removes heat), antipyretic, antitussive and depurative (Yung 1985, Duke and Ayensu 1985). A decoction of root is used in the treatment of ulcers, diphtheria, epidemic Japanese B encephalitis, appendicitis, lymphadenopathy, tonsillitis, parotitis, mastitis and rheumatism. It causes the subsidence of swelling, alleviates pain and relieves boils, carbuncles, sore throat and traumatic pain. It is used as a primary herb in the treatment of liver, stomach, nose, lung, throat and breast cancer in traditional Chinese medicine (Vassilopoulos 2009).

\section{STUDY AREA}

The present study area $\left(28^{\circ} 22.64^{\prime}-28^{\circ} 25.23^{\prime} \mathrm{N}\right.$ latitude and $83^{\circ} 45.87^{\prime}-83^{\circ} 49.98^{\prime} \mathrm{E}$ longitude) lies within Ghandruk Village Development Committee (VDC) of Kaski district which falls under the Annapurna Conservation Area (ACA), Nepal. The forest pattern of VDC shows that sub-tropical region (1000-2000 m) has Riverine forest, Schima-Castanopsis forest and semi-evergreen hill forest; lower temperate region (1500-2500 m) has mixed broadleaved forest and Quercus lamellosa forest; upper temperate region (2500$3500 \mathrm{~m}$ ) has mixed broadleaved forest, Rhododendron forest and Birch forest (Kayastha 1989).

The VDC receives maximum rainfall in July and August (i.e., 762.36 and $755.72 \mathrm{~mm}$, respectively) and minimum in December (i.e., 7.4 $\mathrm{mm})$. The average monthly maximum temperature reaches upto $24.64^{\circ} \mathrm{C}$ in August and minimum temperature falls upto $5.32^{\circ} \mathrm{C}$ in January (according to Lumle station, the nearest station from the study area $\left(28^{\circ} 18^{\prime} \mathrm{N}, 83^{\circ} 48^{\prime} \mathrm{E}, 1740\right.$ masl). 


\section{MATERIALS AND METHODS}

For data collection, field visits were carried out three times (March/April, June and October) in 2008. A technique of random systematic design was applied in which stands are selected by a random or stratified random plan. The sampling sites were selected in four localities Ghandruk (Sityku), Komrong, Chhomrong and Tadapani in such a way that a comparative study can be made in its status on the basis of disturbance factors, altitudinal difference, dryness, etc.

In each locality, five transect lines were set up at an interval of $30-50 \mathrm{~m}$ in Paris polyphylla available site. In each transect line about six quadrats of $1 \mathrm{~m} \times 1 \mathrm{~m}$ were laid down at an interval of $5 \mathrm{~m}$. In each small quadrat, total number of Paris polyphylla plant and its coverage percentage were recorded. $100 \mathrm{~g}$ of soil samples were collected from each subplot from the depth of $25 \mathrm{~cm}$.

For each locality, data were analyzed to assess frequency, density, coverage, biomass and moisture content of the plant by following Zobel et al. 1987. Air dried soil samples were analyzed for total nitrogen $(\%)$, total organic matter $(\mathrm{OM}) \%$, phosphorus $\left(\mathrm{P}_{2} \mathrm{O}_{5} \mathrm{~kg} / \mathrm{ha}\right)$ and potassium $\left(\mathrm{K}_{2} \mathrm{O}\right.$ $\mathrm{kg} / \mathrm{ha}$ ) at Regional Soil Testing Laboratory, Pokhara, Kaski following the methods of soil analysis described in Gupta 2000.

Seed output per plant was calculated by counting the number of seeds present in a single fruit while average seed production per $\mathrm{m}^{2}$ was calculated by multiplying the number of seed output and average density of plant per $\mathrm{m}^{2}$ (Zobel et al.1987).

The seed germination test was carried out under normal condition and under different pretreatment like Gibberllic acid treatment (10 to $100 \mathrm{ppm})$, $\mathrm{NH}_{4} \mathrm{NO}_{3}$ treatment (25 to $400 \mathrm{ppm}$ ) and conc. sulphuric acid treatment ( 5 to $60 \mathrm{~min}$ ). The range of germination period of seed and maximum germination percentage within whole period was calculated.

Seed viability of the plant was tested following Baskin and Baskin (1998) where dissected embryos of seeds were dipped in a $1 \%$ solution of 2, 3, 5 triphenyl-tetrazolium chloride (TTC). The percentage of viability of seed was calculated as follow:

Percentage viability $=\frac{\text { Number of viable seeds } \mathrm{x} 100}{\text { Total number of seeds }}$

\section{RESULTS}

Distribution of Paris polyphylla was at restricted to certain areas in the studied populations. The plant's dominance was seen from forest at $1900 \mathrm{~m}$ just above the huge settlement of Ghandruk, Sitkyu upto $2800 \mathrm{~m}$ at Tadapani. Though the plant showed occurrence at study site around $2900 \mathrm{~m}$, the number was very low.

Paris polyphylla was found in shady, wellmoistened places under the dark canopy of mixed broad leaved forest (Rhododendron forest in Tadapani) except one population in Komrong danda where it was found under open canopy of mixed broad leaved forest.

The highest occurrence of plants found among associated species of Paris polyphylla were Viburnum erubescens, Arisaema, sp., fern, and Sarcococca coriaceae with their frequencies as $35.41 \%, \quad 31.25 \%, \quad 31.16 \%$, and $28.18 \%$, respectively.

\section{Phenology}

Paris polyphylla plant starts germinating in April and flowers in April/May. Seeds mature in October. By the beginning of November to mid November, most of the plant part dies out and all seeds get dispersed. Before the plant dies and after the seed gets matured, bud sprouts on rhizome 
which remains underground for the whole winter until the next germination period (sprouting season). Therefore rhizome is dormant for almost five months. Germination of seeds seems negligible in the wild. Local people reported that very few seeds germinate. Even if it germinates, it starts flowering late and takes many years to produce good yield.

Table 1. Ecological status of Paris polyphylla in different sites.

\begin{tabular}{|c|c|c|c|c|c|c|c|}
\hline $\begin{array}{l}\text { Sampling } \\
\text { sites }\end{array}$ & $\begin{array}{l}\text { Altitude } \\
\quad \text { (m) }\end{array}$ & Frequency \% & $\begin{array}{l}\text { Density } \\
(\mathbf{p l} / \mathbf{m} 2)\end{array}$ & $\begin{array}{c}\text { Coverage } \\
(\%)\end{array}$ & $\begin{array}{c}\text { Plant } \\
\text { height } \\
(\mathrm{cm})\end{array}$ & $\begin{array}{l}\text { Dry mass of } \\
\text { rhizome } \\
\text { (g/plant) }\end{array}$ & $\begin{array}{l}\text { Moisture } \\
\text { content }(\%) \text { in } \\
\text { rhizome }\end{array}$ \\
\hline Ghandruk & $\begin{array}{l}2000- \\
2200\end{array}$ & 40.00 & 1.16 & 33.33 & 41.20 & 8.58 & 65.68 \\
\hline Komrong & $\begin{array}{l}2200- \\
2400\end{array}$ & 43.33 & 1.80 & 41.00 & 49.25 & 7.15 & 61.16 \\
\hline Chhomrong & $\begin{array}{l}2100- \\
2300\end{array}$ & 76.66 & 2.26 & 49.18 & 52.00 & 10.77 & 61.94 \\
\hline Tadapani & $\begin{array}{l}2600- \\
2800\end{array}$ & 83.33 & 1.90 & 42.66 & 48.62 & 7.03 & 64.60 \\
\hline Average & & 60.83 & 1.78 & 41.54 & 47.76 & 8.38 & 63.34 \\
\hline
\end{tabular}

Table 2. Result of Soil test of different locality.

\begin{tabular}{cccccc}
\hline SN & Locality & Organic matter $(\boldsymbol{\%})$ & Total N $(\%)$ & Available P $(\mathbf{k g} / \mathbf{h a})$ & Available K $(\mathbf{k g} / \mathbf{h a})$ \\
\hline 1. & Ghandruk & 12.55 & 0.62 & 33.75 & 611.25 \\
2. & Komrong & 12.45 & 0.61 & 46.0 & 449.50 \\
3. & Chhomrong & 12.02 & 0.60 & 29.25 & 451.25 \\
4. & Tadapani & 12.30 & 0.61 & 35.42 & 582.42 \\
Average & 12.33 & 0.61 & 36.10 & 523.60 \\
\hline
\end{tabular}

Table 3. Measurements of seed of different locality.

\begin{tabular}{llccccc}
\hline SN & Place & $\begin{array}{c}\text { Seed length } \\
(\mathbf{c m})\end{array}$ & $\begin{array}{c}\text { Seed breadth } \\
(\mathbf{c m})\end{array}$ & $\begin{array}{c}\text { Seed fresh } \\
\text { weight }(\mathbf{g})\end{array}$ & $\begin{array}{c}\text { Seed dry } \\
\text { weight }(\mathbf{g})\end{array}$ & $\begin{array}{c}\text { Seed output } \\
(\text { per plant })\end{array}$ \\
\hline 1. & Ghandruk & 0.9 & 0.65 & 2.19 & 0.39 & 44.5 \\
2. & Komrong & 0.8 & 0.6 & 1.64 & 0.26 & 28 \\
3. $\quad$ Chhomrong & 0.95 & 0.75 & 2.74 & 0.53 & 56.4 \\
4. $\quad$ Tadapani & 0.85 & 0.65 & 2.09 & 0.363 & 38.21 \\
Average of all sites & 0.87 & 0.66 & 2.16 & 0.29 & 41.77 \\
\hline
\end{tabular}


Average seed production per $\mathrm{m}^{2}$ was found to be 74.35 seeds per sq. $\mathrm{m}$ (average density of plants for the study area- $1.78 \mathrm{x}$ average seed output per plant- 41.77). Seeds failed to germinate in normal condition and in different pretreatments. Seed viability test showed that $29 \%$ of total seeds treated with TTC were found to be viable.

\section{Local Uses and Harvesting Pattern}

Paris polyphylla has been used by local inhabitants traditionally since ancient times. They use it for fever and headache. They also use it for burns, wounds and many livestock diseases mainly to neutralise poison when the livestock feed on poisonous herbs (bikh). Some people also used it as a medicine for jaundice. Some young people of the village are unaware of its uses. Seeds of the plant were found to be edible and local people ate the seeds of the plant but not for medicinal purposes.

From the survey, mainly two harvest seasons were found for the plant. People harvest the rhizome at the fruiting season (October), just before the plant dies because the yield would be high at this time and also the plant is easily recognizable at its fruiting time (Paris polyphylla and one species of Arisaema are found to be very similar). But the local people especially the Gurungs believe that the plant harvested on Tuesday of mid April (i.e., last Tuesday of Chaitra month) is more effective as a medicine than those harvested at any other season. Besides, these two main seasons, people also harvest the rhizome whenever they visit the forest for fodder collection or for different purposes.

In the past, there used to be large scale collection of rhizomes and were traded to Pokhara city or Kathmandu. But no trade of Paris polyphylla occurs at present. It is banned for commercial collection in this region as it falls under Annapurna Conservation Area.

\section{DISCUSSION AND CONCLUSION}

Though, Paris polyphylla is reported to be found up to $3300 \mathrm{~m}$ in the literature, its distribution was found to be only up to $2800 \mathrm{~m}$ in our study site. Highest population of the plant was observed between $2300 \mathrm{~m}$ to $2700 \mathrm{~m}$. Also, the distribution of herb was not common to all the areas but restricted to certain areas/pockets. Paris polyphylla thrives well with moist and humus rich soil under canopy of forest in full shade to partial shade. The presence of thick litter 1-3 cm deep with almost 40-65\% ground coverage on Paris polyphylla's habitat and the presence of plant near the streams in Ghandruk site also indicate that the plant is adapted to moist and humus rich soil. The plant found under open canopy coverage of forest on Komrong was also under shade of Viburnum erubescens and Sarcococca coriacea which shows that Paris polyphylla is a shade tolerant plant. The lowest density of this plant was found in Ghandruk. This might be due to lower altitude and excessive human encroachment due to the huge settlement of Ghandruk village. There is no previous data on the density of Paris polyphylla plant to compare but according to local people of Ghandruk, there was greater population in the past and the plant could be found easily nearer to the villages.

Frequency of occurrence was relatively better (40-83.33\%) although population density was low. The strong association of Paris polyphylla was seen with the Arisaema species. It was found that the Paris polyphylla plant's absence or presence in an area was easily indicated by the presence and absence of Arisaema in all the study sites. The other associated species were found to be distributed all over the forest but the Paris polyphylla and Arisaema species were found to be distributed in specific areas.

Soil nutrients like organic matter, nitrogen and phosphorus of soil of Paris polyphylla's habitat were higher than the nutrients of soil where the 
plant was absent (data of soil of quadrat without plant). But the potassium content of soil was found to be just the opposite.

\section{Seed biology}

Seed germination is extremely rare in wild. Seed germination did not take place in green house or in laboratory under controlled condition and treating it with different chemicals. It is mentioned that seeds produce primary root about seven months after sowing and then leaves about four months later/second year. Some seeds can remain dormant for a number of years (Vassilopoulos 2009). It is reported that seed dormancy in Paris polyphylla is caused by dynamic changes of several endohormones (Absicic acid decreased, Gibberllic acid and Indole Acetic acid content increased), development of inhibiting substances, and the increase in material accumulation during embryo physiological ripening period (Yun et al. 2006). A single offspring is produced from a single mother plant that also harvested unscientifically leading to rapid decline in its number.

\section{Harvesting Pattern and Sustainability}

According to Gurung culture, people harvest the plant on tuesday of mid April which is the rapid growth period of the plant. This mode of harvest is unsustainable and directly affects the plant population. Another harvest season, September to October is the most appropriate time because by this time, the bud emerges from the rhizome which remains dormant underground till next germination period. If some portion of the rhizome with bud is left underground while harvesting the rhizome of the plant, it will be more sustainable and would help in conserving the plant population in near future.

\section{Management and Conservation}

People reported that among the livestock, sheep and goat eat shoot and fruit of the plant (Paris polyphylla) but cow and buffaloes do not.
Trampling of livestock also destroys the plant habitat. Besides that, overharvesting in the past, unscientific collection of rhizome (in which all the underground parts are removed without leaving any fragment), harvesting of plant before seed maturity, lower number of viable seed production and long dormancy of seeds or very poor seed germination seems to be the major threats to the plant regeneration in the study area. As a consequence, population is declining day by day. People are aware of the declining population of Paris polyphylla but they are unaware about its sustainable harvest.

Paris polyphylla can be cultivated in the study area by creating suitable environment but there has been no such efforts done yet. In Rasuwa district, people of Thulo Syaphru and Brabal VDC have started the small scale cultivation of Paris polyphylla (Prasai 2007). In China, the Yi healers in Chuxiong of Central Yunnan have traditionally grown one variety of Paris polyphylla viz. Paris polyphylla var. yunnanensis in their own agroforestry systems (Long et al. 2003). Large scale cultivation of Paris polyphylla var yunnanensis are being tested in Lameirong village and Dian Nan Village of North West Yunnan, China (Shengji et al. 2006).

The ecological condition of the study area is best suitable for the plant's (Paris polyphylla) growth but its population is at risk and needs to be conserved in time.

\section{ACKNOWLEDGEMENTS}

We sincerely thank the Annapurna Conservation Area Project (ACAP) and Cornell Nepal Study Program for providing the fund to conduct the research. We are grateful to local people of the VDC for their help. We are also thankful to Regional Soil Testing Laboratory Pokhara, Kaski for the soil test. Thanks go to Dr. Bharat Babu Shrestha for his valuable suggestion. 


\section{REFERENCES}

Baral, S.R. and P.P. Kurmi. 2006. A Compendium of Medicinal Plants in Nepal. Mrs. Rachana Sharma. Kathmandu, Nepal.

Baskin, C.C. and J.M. Baskin. 1998. Seeds: Ecology, Biogeography and Evolution of Dormancy and Germination. Academic Press. U.S.A.

Bhattacharyya, N. and S. Sharma. 2008. Assessment of availability, ecological feature, and habitat preference of the medicinal herb Houttuynia cordata Thunb in the Brahmaputra Valley of Assam, India. Environ Monit. Assess. DOI 10.1007/s10661-008-0694-7. Springer Science + Business Media B.V.

Bhattarai, K.R. and M.D. Ghimire. 2006. Cultivation and Sustainable Harvesting of Commercially Important Medicinal and Aromatic Plants of Nepal. Heritage Research and Development Forum, Nepal, pp. 369-372.

CAMP, 2001. Conservation, Assessment and Management Prioritization Report. International Development Research Center (IDRC), Canada and Ministry of Forest and Soil Conservation, Kathmandu, Nepal.

Duke, J.A. and E.S. Ayensu. 1985. Medicinal Plants of China. Reference Publications. ISBN 0-917256-20-1.

Dutta, I.C. 2007. Non Timber Forest Products of Nepal: Identification, Classification, Ethnic Uses and Cultivation. Hillside Press. Kathmandu.

Gupta, 2000. Methods in Environmental Analysis: Water, Soil and Air. Agrobios (India), New Delhi, India.

IUCN Nepal. 2004. National Register of Medicinal and Aromatic Plants (Revised and updated). IUCN-The World Conservation Union, Kathmandu, Nepal. xiii +202 pp.
Kayastha, R. 1989. Floristic Study of The Southern Annapurna Region. National Trust for Nature Conservation. Kathmandu, Nepal.

Liang, S.Y. 2000. Flora of China. Science Press, Beijing and Missouri Botanic Garden, St. Louis. 24:90-91.

Long, C.L., H. Li, Y. Quyang, X. Yang, Q. Li and B. Trangnal. 2003. Strategies for agrobiodiversity conservation and promotion; a case from Yunnan, China. Biodiversity and Conservation 12:1145-1156.

Prasai, D. 2007. Ethnomedicinal Knowledge of Tamang Communities in Rasuwa District, Nepal. M.Sc. thesis submitted to Central Department of Botany, Tribhuvan University, Kirtipur, Kathmandu.

Shengji, P., H. Huying and Y. Lixin. 2006. Important Plant Areas for Medicinal Plants in Chinese Himalaya. National report of China (Government of China).

Tandon, U., N.K. Bhattarai and M. Karki, M. (eds.). 2001. Conservation Assessment and Management Prioritization Report. IDRC Canada/Ministry of Forest and Soil Conservation. Kathmandu, Nepal.

Vassilopoulos, Y. Jan. 2009. Paris Polyphylla. Medicine Section. Newsfinder. A literary favor to world culture.

Yun, M., L. Wang, W. Zhang, X. Li and Y. Wang. 2006. Dynamic changes of several endohormones in embryogenic cells of Paris polyphylla var. yunnanensis during dormancy and different development stages. Journal of Chinese Medicine 34(4):36-37.

Yung, H.C. 1985. Handbook of Chinese Herbs and Formulas. Institute of Chinese Medicine. Los Angeles.

Zobel, D.B., P.K. Jha, M.J. Behan and U.K.R. Yadav. 1987. A Practical Manual for Ecology. Ratna Book Distributors, Kathamandu, Nepal. 